\title{
JUURNAL_RU
}

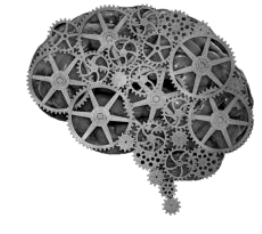

COMPANY GROUP "INTELLEKT"

\author{
Ковтун Д.А., Чепига К.А. \\ Ростовский государственный экономический университет \\ Ростов-на-Дону, Россия
}

doi: 10.18411/lj2016-3-85

\section{Виды угроз экономической безопасности Российской Федерации}

Начиная говорить об угрозах экономической безопасности, необходимо, на наш взгляд, определить причины их появления. Как нам видится, основной причиной наличия данного вида угроз является распад СССР в относительно недалёком прошлом. Объясняется это тем, что отлаженная система старых экономических институтов разрушилась, а на смену пришли новые, ещё не отлаженные механизмы, нуждающиеся, так скажем, в адаптации. Любой вид адаптации несёт с собой ряд проблем, с которыми просто необходимо столкнуться, чтобы проанализировать, понять и внедрить новые знания, умения и навыки для улучшения условий существования. Основной проблемой новых институтов является угроза экономической безопасности страны, которая становится особо актуальной в переходные периоды, сопровождающиеся некоторой уязвимостью не только экономики, но и всех остальных сфер функционирования государства.

Так что же такое экономическая безопасность? Экономическая безопасность - это некое состояние определённого субъекта экономики, характеризующееся постоянным наличием какого-либо ресурса, способного поддержать или улучшить уровень жизни, как в текущий момент, так и в будущем. Для Российской Федерации, как и для любой другой страны, данный вид безопасности характеризуется таким состоянием экономики, при котором государство способно поддерживать уровень социального, политического, 
экономического и оборонного существования и развития, и при этом не зависеть от разного рода внешних и внутренних угроз и воздействий.

Экономические угрозы - факторы, способные серьёзно повлиять на стабильность развития государства по средствам дестабилизации, дезорганизации или полного уничтожения того, что уже было создано. Исходя из определения, можно сделать вывод, что экономические угрозы существовали всегда и везде. Вопрос лишь в том, кто и как с ними справлялся и справляется. Для успешной борьбы с ними необходимо, скажем так, знать врага в лицо. Так давайте же познакомимся.

По самой большой классификации, экономические угрозы подразделяют на внутренние и внешние. Есть и более мелкие классификации, такие как: потенциальные и реальные; угрозы с высокой, средней и низкой тяжестью последствий; по воздействию на предпринимательскую деятельность и многиемногие другие [1]. Давайте остановимся на первой классификации - по источнику возникновения. На наш взгляд, они являются ключевыми.

К внутренним угрозам безопасности можно отнести следующий ряд:

1. Если говорить научным языком, то первая угроза будет иметь название: структурная деформация экономики. Если же перефразировать данное словосочетание, то первая причина: перекос экономики в какую-либо сторону. Например, в настоящий момент, государство выделяет огромные денежные средства на развитие оборонно-промышленного комплекса, несколько жертвуя при этом, например, лёгкой промышленностью. Ситуация может быть и обратная.

2. Чувствительный отток капитала из страны, снижение инвестиционной и инновационной деятельности. Чем это плохо спросите вы, если ещё не знаете. Всё очень просто: без крупных капиталовложений страна просто не сможет выбраться из кризиса. Зачастую, собственных средств не хватает. Будем надеяться, что Россия справится. 
3. Чрезмерная зависимость от топливно-сырьевых ресурсов. Такого рода зависимость начала прослеживаться ещё в 90-ые годы, когда экспорт энергетических ресурсов составлял 80-90 \% от общего экспорта страны. Сейчас все мы можем видеть последствия: цена нефти, на данный день, составляет 41,47 \$ за баррель. При такой цене, российская экономика не просто недосчитывается денег, но и испытывает глубочайшие проблемы с бюджетом, которые не могут не повлиять на население страны. Уровень жизни населения просто на просто падает.

4. Следующая угроза, может быть, в данный момент снизила свою актуальность, но всё же она существует и будет существовать в будущем. Это усиление импортной зависимости от продовольствия и потребительских товаров. Проблема заключается в том, что импортные товары заменяют отечественные, вытесняя их с рынка. В данный момент, санкции способствуют обратной тенденции, однако, всем понятно, что санкции - это мера временная. Когда они будут сняты, далеко не факт, что ситуация не вернётся на круги своя.

5. Отток российского капитала за границу. Это означает, что деньги, которые, по идее, должны работать на российскую экономику, будут работать на иностранную, тем самым ослабевая Россию и усиливая зарубежные страны. Данный факт является предметом изучения для государства: причина утечки капитала; разработка мер по его возвращению; разработка мер по предотвращению подобных ситуаций в будущем.

6. Возрастающее расслоение населения на богатых и бедных, что может привести к социальной нестабильности и напряжённости в обществе. Все мы знаем, люди - главное богатство любой страны. Исходя из этого, не трудно сделать вывод, что недовольное население не способно принести ощутимую пользу успешному развитию страны.

7. Следующая проблема - размер внешнего долга. Несмотря на то, что быть должным кому-то, это уже общепринятая практика, всё же следует 
задумываться над величиной долга. Отвлекая средства на погашение внешнего долга, государство теряет существенную часть бюджетных средств, навлекая на себя недовольство населения, которое сразу же это почувствует.

Вот собственно и все, наиболее проблемные зоны, российской экономике. Но не стоит заблуждаться: и этих угроз хватит на то, что заставить серьёзно задуматься над методами из устранения. Все угрозы объёмные, масштабные, требующие обдуманных действий со стороны руководящих чинов.

К внешним же угрозам относят:

1. Технологическая блокада из-за отставания страны в научно технической cфepe.

2. Продовольственная уязвимость из-за зависимости страны от импорта продуктов питания.

3. Негативное влияние мировых, финансовых, валютных рынков на ещё не окрепший внутренний.

4. Потеря рынков сбыта.

На наш взгляд, всё-таки, все проблемы начинаются с нас самих, соответственно, наибольшее влияние на развитие страны оказывают внутренние проблемы, нежели внешние. Обладая достаточным потенциалом, запасом прочности, ресурсами и многим другим можно рассчитывать если не на неуязвимость от внешних факторов, то, по крайней мере, на их существенное сокращение.

Главной особенность функционирования системы безопасности, на данный момент, является то, что согласно документам по стратегии развития страны до 2020 года, долгосрочной целью является модернизация российской экономики, переход на инновационный путь развития. Если этого не будет достигнуто, то последствия могут быть колоссальными: научное, социальное, экономическое и технологическое отставание России от стран Запада будет уже необратимым процессом. 
Переход на инновационный путь развития предполагает усиление конкурентного потенциала российской экономики за счёт инновационного освоения технологий, науки, образования и так далее. Всё нужно делать самостоятельно, чтобы не было зависимости, от которой все так сильно хотят избавиться [2]. На данный момент, Россия отстаёт от развитых стран Запада почти по всем показателям, характеризующим инновационность экономики. Однако, как уже было сказано, санкции, возможно, могут стать тем рычагом, который запустит механизм перехода, скажем так, на собственные силы.

Опираясь на всё вышесказанное, можно с уверенность сказать, что России необходимо ориентироваться и стремится на такие условия, которые будут способствовать эффективному противодействию экономической безопасности. Следует не только обеспечить безопасность, но и защитить национальные экономические интересы страны на мировой арене. Таким образом, обеспечение экономической безопасности должно стать приоритетной задачей для государства. И только Россия способна справится с ней.

\section{Литература:}

1. Балабанов Б.Б. Глобальные экономические проблемы современности [Текст]: учеб. пособие / под ред. проф. Л.Г. Галкина, М.: БГТУ, 2005. 106с.

2. Дудин М.Н., Н.В. Лясников. Экономическая безопасность России: угрозы национальным интересам и их отражение М.: МГПУ, 2015. 9 с.ГОСТ Р 51232-98. Вода питьевая. Общие требования к организации и методам контроля качества: введен 17 декабря 1998 г., -21с. 